\section{Nutrition in acute renal failure}

\author{
Intensive Care Unit and Nephrology Division, Department of Medicine, \\ Hospital de Base, Faculdade de Medicina de São José do Rio Preto \\ (Famerp), São José do Rio Preto, São Paulo, Brazil
}

- Sérgio Mussi Guimarães

- José Paulo Cipullo

- Suzana Margareth Ajeje Lobo

- Emmanuel de Almeida Burdmann
INTRロDUCTIロN

Approximately $5 \%$ of a hospital's patient population may develop acute renal failure (ARF). ${ }^{1,2}$ This prevalence is even greater among patients in intensive care units (ICUs), where it may reach $16 \%{ }^{3,4} \mathrm{ARF}$ is a severe disease associated with significant mortality rates. In the absence of comorbidity factors, the mortality rate ranges from 7 to $23 \%$, whereas in large series it is around $50 \% .^{2,5}$ Several factors have been correlated with this extremely high mortality rate, such as sepsis, multiple organ failure and oliguria. ${ }^{5-8}$

The patient's nutritional status has also been considered to be a possible mortality factor in ARF cases. Although malnutrition is highly prevalent among hospitalized patients and is associated with increased mortality, ${ }^{9-11}$ the current literature on nutrition in ARF cases is fundamentally based on experimental studies. Most of the clinical studies available have been based on small numbers of patients, retrospectively analyzing surgical or intensive care units (ICU) populations. ${ }^{12-17}$ The sampling problems may result from difficulties in assessing the nutritional status of critically ill patients.

One of the most important initial studies, aimed at evaluating the effect of nutritional therapy in ARF cases was carried out by Abel et al. (1973). ${ }^{12}$ These authors reported lower mortality among ARF patients receiving a combination of essential amino acids and hypertonic glucose, in comparison with patients receiving hypertonic glucose alone. Subsequently, several investigators evaluated the role of nutritional supplementation in morbidity and mortality among ARF patients and obtained conflicting results. ${ }^{13-17}$ These studies were the subject of a meta-analysis carried out by Naylor et al. (1987-88). ${ }^{18}$ This meta-analysis concluded that the survival of ARF patients receiving parenteral nutrition with essential amino acids and hypertonic glucose solutions was better than for those receiving hypertonic glucose alone. However, most of the studies examined had poor descriptions of the randomization criteria and inappropriate statistical analysis, and only two of the four randomized studies included more than 10 patients in each study group. Thus, the authors of the meta-analysis concluded that the efficacy of parenteral nutrition regimens in ARF cases remains unclear.

\section{ENERCY METABDLIBM}

Energy expenditure is defined better in relation to the underlying disease than to acute uremic status, thus suggesting that, when uremia is well controlled, there is little variation in energy metabolism. ${ }^{19-21}$ Energy requirements may be accurately calculated using the HarrisBenedict equation multiplied by the associated stress factor. ${ }^{22}$ Even under hypercatabolic conditions, such as sepsis or organ dysfunction, the energy requirements rarely exceed 1.3 times the baseline energy expenditure. ${ }^{22}$ In ARF cases, an energy intake of 25 to 35 $\mathrm{kcal} / \mathrm{kg} /$ day is recommended, according to the associated degree of catabolism. ${ }^{22}$

\section{PRDTEIN METABDLIISM}

The most marked alteration in nutritional status among ARF patients is the presence of hypercatabolism with a negative nitrogen balance. ${ }^{23}$ Several factors may contribute towards the increased catabolism in ARF cases. Inflammatory mediators, including interleukins and tumoral necrosis factor, activate the protein metabolism in the same way as in other conditions like sepsis that are observed among critically ill patients. Data obtained from animal studies suggest that uremia is associated with increased gluconeogenesis, with increased protein catabolism and reduced protein synthesis. ${ }^{24}$ Hormonal and metabolic

\section{ABSTRACT}

Nutritional status has been considered to be one of the possible determinants of mortality rates in cases of acute renal failure (ARF). However, most studies evaluating possible mortality indicators in ARF cases have not focused on the nutritional status, possibly because of the difficulties involved in assessing the nutritional status of critically ill patients. Although the traditional methods for assessing nutritional status are used for ARF patients, they are not the best choice in this population. The use of nutritional support for these patients has produced conflicting results regarding morbidity and mortality. This review covers the mechanisms and indicators of malnutrition in ARF cases and the types of nutritional support that may be used.

KEY WORDS: Acute kidney failure. Nutrition. Nutritional assessment. Nutrition therapy. Mortality. 
changes, such as insulin resistance, increased glucagon concentrations, secondary hyperparathyroidism and metabolic acidosis have also been correlated with malnutrition among ARF patients. ${ }^{25,26}$

Dialysis procedures cause nutrient loss and stimulate protein catabolism. In low-flux membrane dialysis, 5 to $8 \mathrm{~g}$ of amino acids are lost per session. When high-flux membranes are used, these losses may increase by $30 \%{ }^{27,28}$ The structural characteristics of the dialysis membrane may also influence the nutritional status. The lower the membrane biocompatibility is, the greater the cytokine release related to increased protein catabolism will be, thereby delaying the recovery of ARF and producing worse outcomes. ${ }^{29,30}$ The amount of dialysis may also affect the nutritional status. It is well known that inadequate dialysis doses are associated with worsening of the nutritional status of patients with chronic renal failure. ${ }^{31}$ It has been reported that the delivered dialysis dose in patients with ARF is frequently lower than the prescribed dose, ${ }^{32,33}$ and that uremia induced by suboptimal dialysis is likely to aggravate the protein catabolism.

In experimental ARF models, in addition to increased proteolysis, reduced protein synthesis is also observed. In muscles, the protein degradation rate is increased at the same time as protein synthesis is reduced, even in the presence of insulin. ${ }^{24}$ The inability to improve the nutritional parameters in most ARF patients, despite adequate nutritional therapy, is probably caused by failure to uptake and use the available nutrients. There is evidence that uremia causes abnormalities in the growth hormone/insulin-like growth factor-1 axis and induces resistance to the activity of the growth hormone at a cellular level, thereby hindering the optimal uptake of nutrients. ${ }^{34}$ Concomitant diseases and conditions frequently associated with ARF, such as sepsis and organ failure, also reduce anabolism.

\section{NUTRITIONAL ABSESBMENT IN ACUTE RENAL FAILURE}

Several nutritional assessment methods have been suggested, using clinical, biochemical, anthropometric and body component evaluations. However, no single indicator may be considered to be a "gold standard". Many of the traditional nutritional evaluation methods used in ARF cases are affected by non-nutritional factors, and therefore ought not to be used in this patient population. The most important reason for discrepancies is that several processes play a role in the malnutrition of hypercatabolic patients with ARF. In these patients, malnutrition is a metabolic response to stress or inflammation, whereas under other conditions, malnutrition is predominantly a response to chronic inanition. Nutritional marker variations might differ considerably under these two conditions. ${ }^{32,35}$

\section{INSULIN-LIKE GROWTH FACTOR-1}

Insulin-like growth factor-1 (IGF-1) and insulin-like growth factor-2 (IGF-2) are structurally related to insulin. Human IGFs, generically called somatomedins, are simple chain peptides of 7.5 kilodaltons $(\mathrm{kDa})$, composed of 70 (IGF1) or 67 amino acids (IGF-2). ${ }^{36}$ Four properties, designated $\mathrm{A}, \mathrm{B}, \mathrm{C}$ and $\mathrm{D}$, are identified in IGF molecules, and the $\mathrm{A}$ and $\mathrm{B}$ properties are homologues for the insulin A and B chains. Somatomedins are secreted at the same time as they are produced, and consequently they are not concentrated in any organ. Therefore, although the liver is the major source of circulating somatomedins, ${ }^{37}$ their highest concentration is observed in the blood. ${ }^{38}$ IGFs are produced in several organs and are biologically active in most cell types. ${ }^{39}$ These peptides act through autocrine and paracrine mechanisms, as well as through the classic endocrine mechanisms. ${ }^{40}$ The growth hormone is one of the major hormonal stimuli for IGF-1 production. ${ }^{41}$ Less than $5 \%$ of circulating IGF-1 is free, and over $90 \%$ is tied to other binding proteins. ${ }^{42}$ IGF-1 synthesis is influenced by hormonal and nutritional factors. ${ }^{43}$ In humans, serum IGF-1 levels are reduced after protein-energy deprivation, and return to normal levels within few days after food intake is resumed. ${ }^{44}$ IGF-1 is a reliable marker for nutritional status and has been shown to be better than other biochemical markers for assessing nitrogen balance in severely ill and hypercatabolic patients. ${ }^{45}$ Unterman et al. $(1985)^{46}$ reported that, in malnourished patients, IGF-1 serum levels were better indicators than laboratory tests and the classic anthropometric parameters used to evaluate nutritional status. Donahue and Phillips (1989) ${ }^{47}$ showed that decreased IGF-1 serum levels in hospitalized patients with protein or protein-energy malnutrition $(39 \pm 7 \mathrm{ng} / \mathrm{ml})$ were more marked than in patients with energy malnutrition alone $(109 \pm 25 \mathrm{ng} / \mathrm{ml})$, thus confirming the major role of protein intake in IGF-1 regulation. The good correlation of IGF-1 with nutrient deprivation or intake, its serum stability and short half-life recommend its use as a marker for nutritional status in ARF cases. ${ }^{42,45,48}$

\section{ALBUMIN}

Serum albumin levels decrease markedly in response to stress and inflammation, ${ }^{49}$ and may not accurately reflect nutritional status changes in severely ill patients. The serum half-life of albumin is relatively long (20 days) and serum albumin concentrations change in response to catabolism and nutritional supplementation that take place in the late-stage course of acute diseases. ${ }^{50}$ Hypoalbuminemia has been described as an independent factor for mortality among elderly patients and patients with chronic renal failure undergoing dialysis. ${ }^{51,52}$ However, there is little evidence for an association between decreased serum levels of albumin and mortality in ARF cases. Decreased serum albumin levels have been described by Chertow et al. (1998) ${ }^{6}$ as predictors of mortality among patients with acute tubular necrosis. It should be emphasized that, up to that time, there had not been any reports in the literature to associate hypoalbuminemia with higher mortality in ARF patients. In a study of 15,000 severely ill patients, serum albumin levels $<3.4 \mathrm{~g} / \mathrm{dl}$ on admission were strongly associated with higher mortality, prolonged hospitalization and readmission. ${ }^{52}$

\section{TRANSFERRIN}

Transferrin has a shorter half-life (8 days) than albumin, but it lacks sensitivity for evaluating the short-term effects of refeeding. ${ }^{53}$ Transferrin concentration is significantly influenced by patients' serum iron levels. ${ }^{54}$

\section{PREALBUMIN}

Serum prealbumin is a nutritional marker with a half-life of 1 to 2 days and a good response to nutritional supplementation..$^{53}$ Similarly to albumin, its serum levels decrease in response to stress and inflammation. ${ }^{49} \mathrm{It}$ is excreted mainly by the kidneys. Prealbumin concentrations may be falsely high in patients with ARF.55

\section{BDDY GOMPOSITION ANALYSIS}

The standard techniques for assessing the different body compartments in hospitalized patients were proposed by Blackburn et al. (1977). ${ }^{56}$ Fat storage and the quantification of somatic proteins are usually evaluated by anthropometric measurements. Although these techniques are simple, safe and extensively used to assess body composition in different types of population, they do not have a good clinical correlation in individual analyses. ${ }^{54}$ The use of these methods in ARF cases has limited value, due to the frequent fluid variations observed in this type of patients. Likewise, bioelectrical impedance analysis is a noninvasive, fast, sensitive and accurate method for body composition measurement. ${ }^{55}$ However, its use in ARF cases is also limited due to fluid variations. 


\section{SUBJECTIVE GLDBAL ASSESSMENT}

Subjective global assessment (SGA) is a technique used for evaluating nutritional status. It assesses the nutritional status based on clinical experience and includes the medical and nutritional history, physical examination and functional assessment of the patients. This method was initially developed to assess the nutritional status of surgical patients, ${ }^{57,58}$ but it has now been used in several groups of patients. ${ }^{59,60}$ In patients with chronic renal failure, good correlation has been found between diagnoses of malnutrition made via SGA and objective methods, including biochemistry tests and body composition measurement. ${ }^{59,61}$ Abdullah et al. $(1998)^{62}$ found lower levels of anabolic factors, such as IGF-1, and higher catabolic cytokine levels in patients classified as malnourished via SGA. Worsening of nutritional status, as evaluated by the SGA method in chronic renal patients undergoing peritoneal dialysis, has been correlated with greater mortality risk ${ }^{63}$ although the results from subsequent studies have conflicted with this. ${ }^{64,65}$ Fiaccadori et al. (1999) ${ }^{66}$ reported that nutritional status changes, as assessed by the SGA method, are frequent findings among ARF patients. The same authors reported that preexisting malnutrition, characterized by SGA class $\mathrm{C}$, was an independent predictor for hospital mortality.

Since SGA is a subjective technique, it does not measure visceral proteins and does not provide follow-up for nutritional therapy. Moreover, because it requires information from patients, this methodology may not always be applicable to ARF patients in the ICU, due to their decreased consciousness levels caused by their underlying disease or by the use of sedatives, or because of the use of mechanical ventilation.

\section{TDTAL CHOLESTERDL}

Serum cholesterol is an independent predictor for mortality among hemodialysis patients. Individuals undergoing hemodialysis with normal or low (from 150 to $180 \mathrm{mg} / \mathrm{dl}$ ) serum cholesterol levels have higher mortality than those with higher cholesterol levels. ${ }^{67,68}$ However, the association between hypocholesterolemia and mortality due to non-cardiovascular causes is unclear. ${ }^{69}$ Hypocholesterolemia and decreased low density lipoprotein (LDL) have been described in severely ill surgical patients in the ICU with evidence of sepsis. ${ }^{70}$ It is not clear under what circumstances serum cholesterol might be a reliable indicator of protein-energy malnutrition. Additional data on the associations between serum cholesterol, nutritional status and morbidity and mortality are required.
PATIENT CLABgIFICATION AND NUTRITIONAL THERAPY

The use of adequate nutritional therapy among patients suffering from different diseases is required in order to maintain protein storage and regulate lean body mass deficits. The objectives of nutritional therapy among ARF patients are no different from those under other hypercatabolic conditions. However, they are different from the objectives to be achieved among patients with chronic renal failure (CRF), since therapies meeting the minimum requirements for $\mathrm{CRF}$ are insufficient for ARF patients. ${ }^{22}$

Since not all ARF patients necessarily require nutritional support, it is important to identify those who will benefit from it, as well as to establish the optimal time to start therapy. The decision to start therapy is influenced by the individual's capacity to adequately intake the nutritional requirements, by nutritional status and by the type of underlying disease. When there is evidence of malnutrition or hypercatabolism, therapy should be started early on.

Nutritional requirements are often neglected in clinical practice. Urea nitrogen appearance rate (UNA) measurements, which reflect protein catabolism, ${ }^{22}$ and the assessment of energy requirements are not routine practice. The formulae usually used to calculate energy requirements may underestimate these requirements among ARF patients, since they are based on healthy individuals with normal body fluid distribution.

The undesirable effects of nutritional therapy are another limitation on its use. Excessive supplementation of proteins increases the end products of protein metabolism. The provision of large amounts of nutrients requires the infusion of considerable quantities of fluids, carbohydrates and lipids, and this may cause volume overload and undesirable electrolytic and metabolic changes, such as hyperglycemia, hyperlipidemia, hypernatremia or hyponatremia.
Although most of these changes may be controlled by dialysis, the possibility of such changes induces physicians to use more conservative approaches towards nutritional therapy, thereby inadvertently contributing to a worsening of the nutritional status of ARF patients.

Nutritional programs must be individually designed for each ARF patient. In clinical practice, patients may be divided into three groups, ${ }^{22}$ according to the degree of catabolism, which may be evaluated by calculating the UNA rate (Table 1).

GROUP I: Low UNA rate. These patients are mildly catabolic, i.e. those whose ARF was caused by nephrotoxins alone (aminoglycosides, contrast media and others). Dialysis is seldom required and the use of nutritional therapy containing $25 \mathrm{kcal} / \mathrm{kg} /$ day and $0.6 \mathrm{~g} / \mathrm{kg} /$ day of proteins rich in essential amino acids is usually sufficient. Such patients are usually fed orally and the prognosis for the recovery of renal function and survival is excellent. ${ }^{22}$

GROUP II: Moderate UNA rate. These are ARF patients with moderate catabolism, frequently suffering from infectious or surgical complications. The use of enteral or parenteral nutrition and dialysis is often required. These patients should receive essential and non-essential amino acids at a dose of 0.8 to 1.2 $\mathrm{g} / \mathrm{kg} /$ day and calorie intake of 25 to $30 \mathrm{kcal} /$ $\mathrm{kg} /$ day. The mortality rate in this population is approximately $60 \% .^{22}$

GROUP III: High UNA rate. These are patients who develop ARF in association with severe trauma, severe burn injuries and sepsis. The treatment for this population is complex and includes parenteral nutrition and dialysis. Ventilatory and hemodynamic support are often required. The nutritional requirements for reducing catabolism and minimizing protein depletion are high. The energy requirement is approximately 25 to $35 \mathrm{kcal} / \mathrm{kg} /$ day and the protein requirement is 1.0 to $1.5 \mathrm{~g} / \mathrm{kg} /$ day. The mortality rate in this group is greater than $80 \% .^{22}$
Table 1. Estimating the extent of protein catabolism

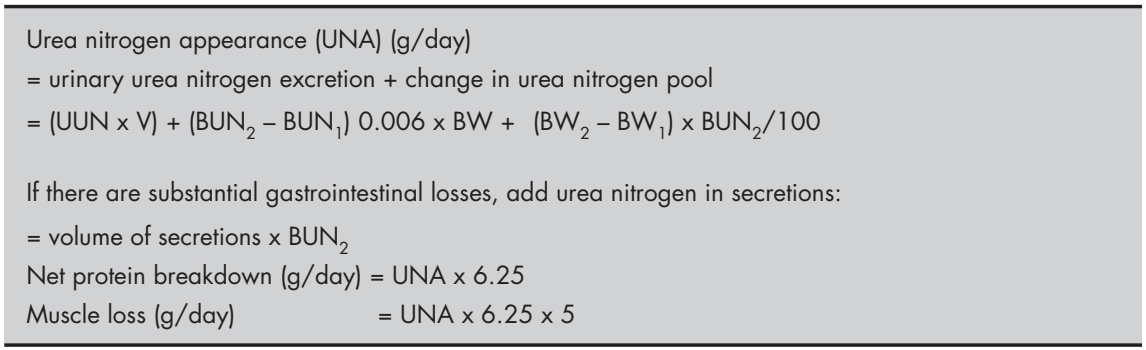

UUN = urinary urea nitrogen concentration in grams nitrogen/day; $V=$ urinary volume in liters; BUN 1 and BUN2 = blood urea nitrogen in mg nitrogen/dl on days 1 and $2 ; B W 1$ and BW2 = body weights in $\mathrm{kg}$ on days 1 and 2 . 
It should be stressed that, in groups II and III, even early and optimized use of nutritional support will hardly be able to offset the marked negative nitrogen balance observed in such patients.

CONCLUSIONS

Nutritional therapy in ARF patients must include an individualized program to meet the nutritional needs of several degrees of stress and hypercatabolism. In these patients, the major determinants of nutritional requirements are not the ARF itself, but the degree of catabolism of the associated diseases, the nutritional status and the type and frequency of dialysis. If there is evidence of malnutrition or hypercatabolism, the therapy should be started early. So far, there is no clear evidence that any specific type of nutritional support is capable of changing the natural history of ARF.
The methods for evaluating the nutritional status and short-term nutritional changes among critically ill patients are insensitive (albumin and anthropometric parameters), have low specificity (transferrin and prealbumin) or are difficult to carry out (nitrogen balance). A sensitive, specific and easy-to-measure marker is clearly required for the early diagnosis of malnutrition in ARF.
1. Hou SH, Bushinsky DA, Wish JB, Cohen JJ, Harrington JT. Hospital-acquired renal insufficiency: a prospective study. Am J Med. 1983;74(2):243-8.

2. Burdmann EA, Oliveira MB, Ferraboli R, et al. Epidemiologia. In: Schor N, Boim M, Dantos DFP, editores. Insuficiência Renal Aguda: Fisiopatologia, Clínica e Tratamento. $1^{\text {st }}$.ed. São Paulo: Sarvier; 1997. p. 1-7.

3. Groeneveld AB, Tran DD, van der Meulen J, Nauta JJ, Thij LG. Acute renal failure in the medical intensive care unit: predisposing, complicating factors and outcome. Nephron. 1991;59(40):602-10.

4. Schwilk B, Wiedeck H, Stein B, Reinelt H, Treiber H, Bothner U. Epidemiology of acute renal failure and outcome of haemodiafiltration in intensive care. Intensive Care Med. 1997;23(12):1204-11

5. Levy EM, Viscoli CM, Horwitz RI. The effect of acute renal failure on mortality. A cohort analysis. JAMA. 1996;275(19):1489-94

6. Chertow GM, Lazarus JM, Paganini EP, Allgren RL, Lafayette RA, Sayegh MH. Predictors of mortality and the provision of dialysis in patients with acute tubular necrosis. The Auriculin Anaritide Acute Renal Failure Study Group. J Am Soc Nephrol. 1998;9(4):692-8.

7. Chertow GM, Christiansen CL, Cleary PD, Munro C, Lazarus JM. Prognostic stratification in critically ill patients with acute renal failure requiring dialysis. Arch Intern Med. 1995;155(14):1505-11.

8. Brivet FG, Kleinknecht DJ, Loirat P, Landais PJ. Acute renal failure in intensive care units - causes, outcome, and prognostic factors of hospital mortality: a prospective, multicenter study. French Study Group on Acute Renal Failure. Crit Care Med. 1996;24(2):192-8.

9. McWhirter JP, Pennington CR. Incidence and recognition of malnutrition in hospital. BMJ. 1994;308(6934):945-8.

10. Bistrian BR, Blackburn GL, Hallowell E, Heddle R. Protein status of general surgical patients. JAMA. 1974;230(6):858-60.

11. Owen WF, Lew NL, Liu Y, Lowrie EG, Lazarus JM. The urea reduction ratio and serum albumin concentration as predictors of mortality in patients undergoing hemodialysis. N Engl J Med. 1993;329(14):1001-6.

12. Abel RM, Beck CH, Abbott WM, Ryan JA, Barnett GO, Fischer JE. Improved survival from acute renal failure after treatment with intravenous essential $\mathrm{L}$-amino acids and glucose. Results of a prospective, double-blind study. N Engl J Med. 1973;288(14):695-9.

13. Baek SM, Makabali GG, Bryan-Brown CW, Kusek J, Shoemaker WC. The influence of parenteral nutrition on the course of acute renal failure. Surg Gynecol Obstet. 1975;141(3):405-8.

14. McMurray SD, Luft FC, Maxwell DR, et al. Prevailing patterns and predictor variables in patients with acute tubular necrosis. Arch Intern Med. 1978;138(6):950-5.

15. Mirtallo JM, Schneider PJ, Mavko K, Ruberg RL, Fabri PJ. A comparison of essential and general amino acid infusions in the nutritional support of patients with compromised renal function. JPEN J Parenter Enteral Nutr. 1982;6(2):109-13.
16. Pelosi G, Proietti R, Arcangeli A, Magalini SI, Bondoli A. Total parenteral nutrition infusate. An approach to its optimal composition in post-trauma acute renal failure. Resuscitation. 1981;9(1):45-51.

17. Feinstein EI, Blumenkrantz MJ, Healy M, et al. Clinical and metabolic responses to parenteral nutrition in acute renal failure. A controlled double-blind study. Medicine (Baltimore). 1981;60(2):124-37.

18. Naylor CD, Detsky AS, O'Rourke K, Fonberg E. Does treatment with essential amino acids and hypertonic glucose improve survival in acute renal failure? A meta-analysis. Ren Fail. 1987-88;10(3-4):141-52

19. Om $\mathrm{P}$, Hohenegger M. Energy metabolism in acute uremic rats. Nephron. 1980;25(5):249-53.

20. Schneeweiss B, Graninger W, Stockenhuber F, et al. Energy metabolism in acute and chronic renal failure. Am J Clin Nutr. 1990;52(4):596-601.

21. Soop M, Forsberg E, Thörne A, Alvestrand A. Energy expenditure in postoperative multiple organ failure with acute renal failure. Clin Nephrol. 1989;31(3):139-45.

22. Druml W. Nutritional support in acute renal failure. In: Handbook of nutrition and kidney. Mitch WE, Klahr S, editors. Philadelphia: Lippincott Williams \& Wilkins; 2002. p. 191-213.

23. Druml W. Protein metabolism in acute renal failure. Miner Electrolyte Metab. 1998;24(1):47-54.

24. Clark AS, Mitch WE. Muscle protein turnover and glucose uptake in acutely uremic rats. Effects of insulin and the duration of renal insufficiency. J Clin Invest. 1983;72(3):836-45.

25. Kopple JD, Cianciaruso B, Massry SG. Does parathyroid hormone cause protein wasting? Contrib Nephrol. 1980;20:138-48.

26. Franz $\mathrm{M}, \mathrm{Hörl} \mathrm{WH}$. Protein catabolism in acute renal failure. Miner Electrolyte Metab. 1997;23(3-6):189-93.

27. Ikizler TA, Flakoll PJ, Parker RA, Hakim RM. Amino acid and albumin losses during hemodialysis. Kidney Int. 1994;46(3):830-7.

28. Hynote ED, McCamish MA, Depner TA, Davis PA. Amino acid losses during hemodialysis: effects of high-solute flux and parenteral nutrition in acute renal failure. JPEN J Parenter Enteral Nutr. 1995;19(1):15-21.

29. Hakim RM. Clinical implications of hemodialysis membrane biocompatibility. Kidney Int. 1993;44(3):484-94.

30. Hakim RM, Wingard RL, Parker RA. Effect of the dialysis membrane in the treatment of patients with acute renal failure. N Engl J Med. 1994;331(20):1338-42.

31. Hakim RM, Breyer J, Ismail N, Schulman G. Effects of dose of dialysis on morbidity and mortality. Am J Kidney Dis. 1994;23(5):661-9.

32. Ikizler TA, Himmelfarb J. Nutrition in acute renal failure patients. Adv Ren Replace Ther. 1997;4(2 Suppl 1):54-63.

33. Luyckx VA, Bonventre JV. Dose of dialysis in acute renal failure. Semin Dial. 2004;17(1):30-6

34. Friedlaender MM, Fervenza FC, Tsao T, Hsu F, Rabkin R. The insulin-like growth factor-I axis in acute renal failure. Ren Fail. 1998;20(2):343-8
35. Boosalis MG, Ott L, Levine AS, et al. Relationship of visceral proteins to nutritional status in chronic and acute stress. Crit Care Med. 1989;17(8):741-7.

36. Daughaday WH, Rotwein P. Insulin-like growth factors I and II. Peptide, messenger ribonucleic acid and gene structures, serum, and tissue concentrations. Endocr Rev. 1989;10(1):68-91.

37. Schwander JC, Hauri C, Zapf J, Froesch ER. Synthesis and secretion of insulin-like growth factor and its binding protein by the perfused rat liver: dependence on growth hormone status. Endocrinology. 1983;113(1):297-305.

38. Furlanetto RW, Underwood LE, Van Wyk JJ, D’Ercole AJ Estimation of somatomedin-C levels in normals and patients with pituitary disease by radioimmunoassay. J Clin Invest. 1977;60(3):648-57.

39. D'Ercole AJ, Stiles AD, Underwood LE. Tissue concentrations of somatomedin C: further evidence for multiple sites of synthesis and paracrine or autocrine mechanisms of action. Proc Natl Acad Sci USA.1984;81(3):935-9.

40. Holly JMP, Wass JA. Insulin-like growth factors; autocrine, paracrine or endocrine? New perspectives of the somatomedin hypothesis in the light of recent developments. J Endocrinol. 1989;122(30):611-8.

41. Copeland KC, Underwood LE, Van Wyk JJ. Induction of immunoreactive somatomedin $\mathrm{C}$ human serum by growth hormone: dose-response relationships and effect on chromatographic profiles. J Clin Endocrinol Metab. 1980;50(4):690-7.

42. Thissen JP, Ketelslegers JM, Underwood LE. Nutritional regulation of the insulin-like growth factors. Endocr Rev. 1994;15(1):80-101.

43. Clemmons DR, Van Wyk JJ. Factors controlling blood concentrations of somatomedin C. Clin Endocrinol Metab. 1984;13(1):113-43.

44. Isley WL, Underwood LE, Clemmons DR. Dietary components that regulate serum somatomedin-C concentrations in humans. J Clin Invest. 1983;71(2):175-82.

45. Hawker FH, Stewart PM, Baxter RC, et al. Relationship of somatomedin-C/insulin-like growth factor I levels to conventional nutrition indices in critically ill patients. Crit Care Med. 1987;15(8):732-6.

46. Unterman TG, Vazquez RM, Slas AJ, Martyn PA, Phillips LS Nutrition and somatomedin. XIII. Usefulness of somatomedinC in nutritional assessment. Am J Med. 1985;78(2):228-34.

47. Donahue SP, Phillips LS. Response of IGF-1 to nutritional support in malnourished hospital patients: a possible indicator of short-term changes in nutritional status. Am J Clin Nutr. 1989;50(5):962-9.

48. Jacob V, Le Carpentier JE, Salzano S, et al. IGF-1, a marker of undernutrition in hemodialysis patients. Am J Clin Nutr. 1990;52(1):39-44

49. Gabay C, Kushner I. Acute-phase proteins and other systemic responses to inflammation. N Engl J Med. 1999;340(6):448-54.

50. Phang PT, Aeberhardt LE. Effect of nutritional support on routine nutrition assessment parameters and body composition in intensive care unit patients. Can J Surg. 1996;39(3):212-9. 
51. Culp K, Flanigan M, Lowrie EG, Lew N, Zimmerman B. Modeling mortality risk in hemodialysis patients using laboratory values as time-dependent covariates. Am J Kidney Dis. 1996;28(5):741-6.

52. Herrmann FR, Safran C, Levkoff SE, Minaker KL. Serum albumin level on admission as a predictor of death, length of stay, and readmission. Arch Intern Med. 1992;152(1):125-30.

53. Church JM, Hill GL. Assessing the efficacy of intravenous nutrition in general surgical patients: dynamic nutritional assessment with plasma proteins. JPEN J Parenter Enteral Nutr. 1987;11(2):135-9.

54. Bernard MA, Jacobs DO, Rombeau JL. Suporte nutricional e metabólico de pacientes hospitalizados. In: Bernard MA, Jacobs DO, Rombeau JL, editores. Avaliaçăo nutricional. Rio de Janeiro: Guanabara; 1988. p. 24-42.

55. Goldstein-Fuchs DJ. Assessment of nutritional status in renal diseases. In: Handbook of nutrition and kidney. Mitch WE, Klahr S, editors. Philadelphia: Lippincott Williams \& Wilkins; 2002. p. 42-92.

56. Blackburn GL, Bistrian BR, Maini BS, Schlamm HT, Smith MF. Nutritional and metabolic assessment of the hospitalized patient. JPEN J Parenter Enteral Nutr. 1977;1(1):11-22.

57. Baker JP, Detsky AS, Wesson DE, et al. Nutritional assessment: a comparison of clinical judgement and objective measurements. N Engl J Med. 1982;306(16):969-72.
58. Detsky AS, McLaughlin JR, Baker JP, et al. What is subjective global assessment of nutritional status? JPEN J Parenter Enteral Nutr. 1987;11(1):8-13.

59. Kalantar-Zadeh K, Kleiner M, Dunne E, et al. Total iron-binding capacity-estimated transferrin correlates with the nutritional subjective global assessment in hemodialysis patients. Am J Kidney Dis. 1998;31(2):263-72.

60. Hasse J, Strong S, Gorman MA, Liepa G. Subjective global assessment: alternative nutrition-assessment technique for livertransplant candidates. Nutrition. 1993;9(4):339-43.

61. Enia G, Sicuso C, Alati G, Zoccali C. Subjective global assessment of nutrition in dialysis patients. Nephrol Dial Transplant. 1993;8(10):1094-8.

62. Abdullah MS, Wild G, Jacob V, et al. Cytokines and the malnutrition of chronic renal failure. Miner Electrolyte Metab. 1997;23(3-6):237-42.

63. Adequacy of dialysis and nutrition in continuous peritoneal dialysis: association with clinical outcomes. Canada-USA (CANUSA). Peritoneal Dialysis Study Group. J Am Soc Nephrol. 1996;7(2):198-207.

64. Maiorca R, Cancarini GC, Brunori G, et al. Comparison of long-term survival between hemodialysis and peritoneal dialysis. Adv Perit Dial. 1996;12:79-88.

65. Maiorca R, Brunori G, Zubani R, et al. Predictive value of dialysis adequacy and nutritional indices for mortality and morbidity in CAPD and HD patients. A longitudinal study. Nephrol Dial Transplant. 1995;10(12):2295-305.
66. Fiaccadori E, Lombardi M, Leonardi S, Rotelli CF, Tortorella $\mathrm{G}$, Borghetti A. Prevalence and clinical outcome associated with preexisting malnutrition in acute renal failure: a prospective cohort study. J Am Soc Nephrol. 1999;10(3):581-93.

67. Lowrie EG, Huang WH, Lew NL. Death risk predictors among peritoneal dialysis and hemodialysis patients: a preliminary comparison. Am J Kidney Dis. 1995;26(1):220-8.

68. Husebye DG, Westlie L, Styrvoky TJ, Kjellstrand CM. Psychological, social, and somatic prognostic indicators in old patients undergoing long-term dialysis. Arch Intern Med. 1987;147(11):1921-4

69. Liu Y, Coresh J, Eustace JA, et al. Association between cholesterol level and mortality in dialysis patients: role of inflammation and malnutrition. JAMA. 2004;291(4):451-9.

70. Gordon BR, Parker TS, Levine DM, et al. Low lipid concentrations in critical illness: implications for preventing and treating endotoxemia. Crit Care Med. 1996;24(4):584-9.

Sources of funding: Not declared Conflict of interest: Not declared Date of first submission: March 24, 2004

Last received: April 7, 2005

Accepted: April 7, 2005

\section{AUTHOR INFLRMATION}

Sérgio Mussi Guimarães, MD. Assistant professor, Intensive Care Unit, Department of Medicine, Hospital de (Famerpl, São Jó́ do Rio Pra de São José do Rio Pret

São Paulo, Brazil.

José Paulo Cipullo, MD, PhD. Adjunct professor, Nephrology Division, Department of Medicine, Hospital de (Famerp), São José do Rio Preto, São Paulo, Brazil.

Suzana Margareth Ajeje Lobo, MD, PhD. Adjunct professor, Intensive Care Unit, Department of Medicine, Hospital de Base, Faculdade de Medicina de São José do Rio Preto, São José do Rio Preto, São Paulo, Brazil.

Emmanuel de Almeida Burdmann, MD, PhD. As sociate professor, Nephrology Division, Department of Medicine, Faculdade de Medicina de São José do Rio Preto (Famerp), São José do Rio Preto, São Paulo, Brazil.

Address for correspondence:

Sérgio Mussi Guimarães

Rua Dr. Carlos de Arnaldo Silva, 110

- Jardim Palmeiras

São José do Rio Preto (SP) - Brasil - CEP 15093-000

Tel.(+55 17) 227-8239

E-mail: sergiomussi@terra.com.br
RESUMD

Nutrição na insuficiência renal aguda

O estado nutricional tem sido considerado como um dos possíveis determinantes da taxa de mortalidade em insuficiência renal aguda. No entanto, na maioria dos estudos que avaliam possíveis preditores de mortalidade na insuficiência renal aguda, pouca atenção tem sido dada ao estado nutricional, possivelmente em função das dificuldades de sua avaliação em pacientes críticos. Embora os métodos tradicionais de avaliação nutricional sejam usados na insuficiência renal aguda, estes não são os mais indicados para esta população de pacientes. O uso de suporte nutricional nestes pacientes tem originado resultados conflitantes em relação à morbidade e à mortalidade. Esta revisão aborda os mecanismos e marcadores de desnutrição na insuficiência renal aguda e os possíveis procedimentos de suporte nutricional a serem realizados.

PALAVRAS-CHAVE: Insuficiência renal aguda. Nutrição. Avaliação nutricional. Terapia nutricional. Mortalidade. 